\title{
Comparing Subject of Assignment of Contract with Similar Concepts of Other Countries' Domestic Laws and International Documents
}

\author{
Naser Alidousti ${ }^{1}$, Ebrahim Taghizadeh ${ }^{2}$, Mehdi Ashouri ${ }^{3} \&$ Ali Khosravi Farsani ${ }^{4}$ \\ ${ }^{1}$ Group of Private Law, University of Judicial Sciences and Administrative Services, Iran \\ ${ }^{2}$ Group of Private Law, High Education Department, Payam-e-Nour University of Tehran, Iran \\ ${ }^{3}$ Group of Private Law, University of Shahrekord, Iran \\ ${ }^{4}$ High Education Department, Payam-e-Nour University of Tehran, Iran \\ Correspondence: Naser Alidousti, Group of Private Law, University of Judicial Sciences and Administrative \\ Services, Iran. E-mail:dr.alidoosti@yahoo.com
}

\author{
Received: February 14, 2016 Accepted: March 8, 2016 Online Published: March 31, 2016 \\ doi:10.5539/jpl.v9n2p173 URL: http://dx.doi.org/10.5539/jpl.v9n2p173
}

\begin{abstract}
In concluding a contract, the thing being concluded and assigned is a contract which is a credit existence considered as object of assignment. However in assigning liabilities and debts, the thing being assigned is a debt, which is called debt for the debtor and right for the creditor, whether this liability or debt is due to a contract or due to a crime or civil liability and tortious liability. In novation, what is important is fall of the previous obligation and establishment of the new one. Hence in novation you cannot only rely on assigning obligation with the previous status, since the previous obligation does not remain anymore. This is while making an contract has this advantage that without any necessity to fall of the previous obligation, position of the obligor and obligee can be replaced. Each contract, from viewpoint of each of the parties to the contract, bears two parts including rights and obligations. According to the aforementioned issues, rights and obligations can be assigned separately. Now, when one party to the contract assigns both rights and obligations caused by a contract in a legal action, actually an assignment of contract has occurred. In other words, assignment of contract is total assignment of rights and assignment of obligations. Therefore, in comparing these subjects, assignment of contract is general and the other two are specific.
\end{abstract}

Keywords: assignment of contract, assignment of right, assignment of debt, novation, secondary contract, assignment of rights and assignment of obligations

\section{Introduction}

Assignment of contract means that a person after concluding a contract, transfers his position in terms of being a party to the contract to another person (Ghomami, 1998:15). Therefore, assignment of contract shall not be mistakenly interpreted as wholly or partly assignment of rights caused by a contract or the obligation due to it. In assignment of a contract, the party to the contract steps out of the legal relationship and another person is substituted and from that moment is considered as the party to the contract and can claim the rights caused by the contract and is also liable against liabilities caused by the contract. Sometimes, assignment of contract is made by act of law and without interfere of wills of parties and this type is called forcible or legal assignment. This type of assignment sometimes occurs following conclusion of a legal action such as a contract or unilateral obligation and occurs as a forcible effect. For instance, in article 498 of Civil Code, on forcible assignment of lease after selling the object of lease, or sometimes a legal event such as death causes assignment of some of the contracts to the heirs. Assignment of contract is sometimes as a result of decision of a judicial authority, for instance, the order which is subject of article 19 of the act governing relationship between lessee and lessor approved in 1977 in which the court allowed assignment of contract and is called "Judicial Assignment". Nevertheless, assignment of a contract occurs in the form of an independent contract and by will of the assignee and assigner and permission of the other party to the contract. In English Law, assignment of rights of a contract, usually, does not bear any responsibility for the assignee, unless explicitly admits execution of obligations (Treitel, 1997: 618). However, in some cases, the condition of enjoying rights of a contract is to bear its obligation, since in such cases, contract obligations are so joined to the contract rights that assigning the rights 
requires assigning obligation. In such cases where assignment of rights of a contract are considered as its benefit, bears obligation for the assignee for executing contractual obligations (burden of contract) and this principle is called Pure principle of Benefit and Burden and it indicates the relation between rights and obligations (Ibid: 619) (Note 1).

In American Law, the issue of assignment of contract has a more legal aspect, so that this subject in law of contracts is called "Assignment of Contract", and in Uniform Commercial Code of America ${ }^{1}$, on issue of sales and lease, assignment of contract is also regarded. In this regard, in article 2210, this act was mentioned on contract of sale, assignment of rights and entrusting obligations of a sale, and by virtue of clause 4 of this act, assignment of contract or assignment of all rights of a contract, means both assignment of rights of a contract and execution of obligations, unless the terms used and conditions governing the situation refer to an opposite meaning and indicate that the views of both parties were pointing merely to assignment of rights of the contract.

In considering current laws of Iran, it can be observed that there is not a specific and independent chapter under the title of assignment of contract or assignment of contract. However, definitely it doesn't mean this subject is not admitted in our legal system, but in numerous cases, directly or indirectly, some regulations have been passed which a number of them will be mentioned in the following. In Islamic Law discussions, venerable Shiite jurists have not discussed an independent chapter for assignment of contract, but regarding this subject, they have discussed in the form of contracts such as Commandite, Muzara'eh, Lease, etc., so that from their explanation you can interpret that this subject is not specifically for the described contracts, but it can be considered as a part of general principles of contracts.

Definitely, investigating all aspects of the subject of assignment of contract is not possible in this discussion, but it is of a high importance to separate this subject from similar concepts. Hence, a superficial introduction to this subject, on similar concepts to the assignment of contract such as novation, assignment of right, assignment of obligations which are objects to the contract, etc., will be compared in this paper with the subject of assignment of contract in the form of concept mentioned above. It should be noted that, international documents used in this paper are Principles of European Contract Law and Principles of International Commercial Contracts, since in the text of the international sale of goods convention, the subject of assignment of contract has not been mentioned, but in the other two documents, there are some regulations which will be considered.

\section{Subjects Similar to Assignment of Contracts in Laws of Countries}

\subsection{Assignment of Right and Assignment of Debt}

Assignment of right is a contract through which a creditor assigns his right to another person, without interfere of the debtor in this contract (Jafari Langeroudi, 2007, Vol.1:675).

In the third clause of article 292 of the Civil Code, and also article 26 of Insurance Law approved in 1937, admittance of subject of assignment of right can be observed ${ }^{2}$.

In the second clause of article 292 of the Civil Code and also article 17 of Insurance Law approved in 1937 , assignment of debt was admitted by the legislator ${ }^{3}$. It is observed that assignment of right and assignment of debt, are considered as contracts, as well as assignment of contract.

\section{U.C.C: Uniform Commercial Code}

Uniform commercial code of America which was firstly published in 1952 is one of the uniform laws which has attempted to unify laws related to contracts included in all 50 States of America. Some States made formal alterations in the said code. Though the said code is related to domestic law of America, since it is accepted in all States of America, it is of a high importance in comparative studies.

2. Article 292 of Civil Code has discussed assignment of right and debt under the title of novation, but these two are different that in description of the coming section related to novation, it will be discussed. Therefore, in article 292 of Civil Code it is stipulated that: "Obligation alteration can be done in the following cases:

2.1. When obligor and obligee agree on alteration of the main obligation to a new obligation which is substituted for it for a reason. In this case, the obligor would become free of the mian obligation.

\subsection{When the third party with consent of the obligee agrees to pay debt of the obligor.}

2.3. When the obligee assigns obligation of the obligor to another person". And article 26 of Insurance law stipulates that: "During all period of contract of life insurance, the insurer has right to assign a specific amount in the policy to another person, the said assignment shall be signed by the assigner and the insurer."

4. Article 17 of Insurance law has stipulated that: "In case of death of the insured or assignment of the object of 
insurance to another person, if the heirs or assignee performs all obligations which shall be borne by the insured against the insurer, insurance contract will remain effective, yet, either the insurer, heir, or assignee will have right of cancellation..."

On satisfaction and intention of both parties, since assignment of right will be conducted through mutual agreement of assignee and assigner, it is not necessary to follow a specific procedure, since from provisions of article 190 of Iranian Civil Code it can be interpreted that contracts must be based on mutual consent, and the opposite situation which refers to a formal contract, requires stipulation of the legislator. However, if the purpose of assignment of right is to give it as a gift to the assignee, the principle of being based on mutual consent in foreign legal systems is encountered an exception. For instance, in French Law, gratuitous assignment of right requires observance of procedures related to direct gift and also drawing up official document of assignment, or according to article 136 of property act approved in 1925 in England, one of the conditions of correctness of "assignment based on statute" is to be written. However, since in Iranian Law gift of right is possible only to the debtor and according to article 800 of Civil Code, if it is in hand of the donee, it doesn't need to be taken again, so it doesn't seem that the principle of being based on mutual consent in contract of assignment of right encounters any defect (Salajegheh, 2000:209).

It should be mentioned that in Common Law, the subject of assignment of debt is not admitted and for compensating this deficit, subjects of Delegation of Performance and Novation are used (Shoarian, 2009:238). In French Law, direct assignment of debt is not recognized. Articles 414 to 419 of German Civil Code and article 176 of Swiss Code of Obligations, assignment of debt is admitted. Former Civil Code of Egypt, following the French Law, didn't admit assignment of debt, but in article 315 of the new Civil Code of Egypt, assignment of debt is recognized and this recognition can be observed in article 315 of Syrian Civil Code, article 302 of Libyan Civil Code, article 339 of Iraq Civil Code, and also article 217 of Code of Contracts and Obligations of Lebanon (Al-Sanhouri, 1986:419,439,561,562).

Therefore, assignment of right and debt as well as assignment of contract are considered as contracts. Either in assignment of debt or assignment of contract, consent of the main party to the contract is necessary, unlike assignment of right in which consent of the main party is not necessary. In all of the abovementioned three subjects, the previous legal relationship remains and this issue indicates the distinction with novation.

Death is the cause of forcible assignment of debt from estate-leaver to heir (Shahidi, 2004:150) and subordinate assignment of debt is conducted through assignment of a property to which debt is attached and called by a number of people as indirect assignment of debt (Katouzian, 2004:284). However, according to the aforementioned issues assignment of debt and right are different with assignment of contract. First, in assignment of contract, the thing being assigned is a contract that as a credit existence becomes the object of assignment, but in assignment of debt and right, the thing being assigned is a debt which is called debt in view of the debtor and called right in view of the creditor, whether this debt or right is due to a contract, crime, civil obligation, or tortious liability. Second, in assignment of a contract, assignee substitutes the assigner and all contractual rights and obligations are assigned to him. For instance, right of cancellation, action, claim for contractual obligations are recognized for him, while in assignment of debt and right, even if this debt and right is due to a contract, the assignee will not have a position in that contract and his only right is to claim the assigned right and his only obligation is to pay the assigned debt. It should be mentioned that in assignment of contract, the past rights and obligations will not be waived, but will be assigned with the same status. Also on assignment of debt or right, existing debt or right will be assigned with the same status, meaning that the past right or debt will not be waived so that new ones would be established, but it is not any more obligation of the debtor or the obligor and is of the assignee. However, on the contrary, in American and English Law, according to clause 1 of article 2-210 of the Uniform Commercial Code, in the subject of Delegation of Performance, after assigning execution of obligations, obligation will not be waived from the first obligor.

In French Law, article 1717 of Civil Code, assignment of lease is recognized as meaning of assignment of rights and obligations, though, obligation of the former lessee remains effective even after assignment of the lease, unless the proprietor waives him (Planiol and Ripert, 1939: 68). The reason of this fact refers to non-recognition of assignment of debt in law of this country.

\subsection{Novation}

Agreement between the obligee and obligor on replacing the previous obligation with the new one is called novation. Because of this contractual change, it should be called novation contract, but in legal texts it is briefly called novation (Ghasemzadeh, 2004:184). Therefore, novation is a type of contract between obligee and obligor. Object of this contract is to replace the previous obligation with the new one. Through novation, the previous 
obligation and its guarantees are waived and the new obligation is replaced.

The creditor can assign his right to another person. In assignment of right, consent of the debtor and even his awareness about assignment of right is not necessary, since right is considered as properties of the creditor and he can assign his property to whoever he wishes, and definitely acceptance of the assignee or his representative is necessary. However, the novation contract is concluded between the obligor and obligee and mutual consent, intention, and capacity of both parties are required.

Novation is different with assignment of debt. In novation, the previous obligation is waived and the new one is replaced. While, in assignment of debt, no debt or obligation is waived and the debt is assigned from the debtor to a third party in the same status. Whenever the third party admits it, obligation will be waived from the original debtor. In Iranian Law, by realization of the contract of guarantee (article 684 of Civil Code) and contract of assignment (article 724 of Civil Code), obligation of debt is assigned from debtor to the guarantor and drawee.

Assignment of contract in American and English Law has been studied in two parts such as assignment of rights and assignment of obligations and their laws are different. In the primary common law, the only way of assignment of contractual rights was by using subject of novation, so that after a while, by attempts of judges and judgments of courts, severities were decreased and the process of assignment of right was recognized in common law. In assignment of contract, in which contractual rights are assigned, issue of novation is not regarded. In laws of the both countries, assignment of right is performed as a property with exchange value, without need for agreement of the debtor (Kotz, 1992: 52).

However, the part related to assignment of obligations is different. In laws of both countries, assignment of contractual obligation in a real form is not possible and in order to achieve the purpose of interest (novation), various solutions have been considered. Writers of English Law unanimously believe that common law does not recognize assignment of contractual obligation in a manner that obligation is assigned from the party to the contract to another person, but for compensating this deficiency, other solutions have also been considered. Four common methods are novation, vicarious performance, operation of law, and principle of benefit and burden, and in such cases, actual assignment of obligation would not be realized (Treitel, 1989: 242).

It is obvious that assignment of obligations in fact refers to execution of contractual obligations by substitute of the obligor, and still obligation remains for the assignor and no assignment of obligation is conducted in this case. However, if the purpose is that responsibility of the assigner toward contractual obligations be waived, and only the assignee be responsible for executing the contract, the only possible way will be using the method of novation. Therefore, if the assignee in addition to rights, also accepts contractual obligations, and the original party to the contract (assigner) waives him, novation will be conducted (Corbin, 1964: 811).

In Egyptian Law, assignment of lease is subject to assignment of right and debt and its nature is not considered as novation (Al-Sanhouri, 1986, Vol.6:699).

Therefore, either in assignment of contract or novation, because of changing the obligee or the obligor, a legal action of contractual type is occurred, so that its result is change of party to the contract. But these two legal actions are different from each other from various aspects as follows:

Firstly, in novation, the important effect is waiver of the previous obligation and establishment of the new one. Hence, in novation, assignment of obligation with the same status has not been occurred, since the previous obligation does not remain any more. This is while assignment of contract has this advantage that without need for waiving the previous obligation, replaces the position of obligee and obligor. For instance, it cannot be stated that by assignment of lease contract the previous lease is waived and the new lease between the assignee and party to the contract is performed, but by maintenance of the contract, only the parties are changed. It should be mentioned that the subject of novation is the legacy of romans and is related to the time when obligation couldn't be assigned to others and whenever assignment of obligation was necessary, both parties to the obligation (debtor and creditor) had to waive the obligation and replace it with the requested obligation and for this action, a separate legal action including waiving the previous obligation and establishing the new one would be performed. After that, the novation merged these two legal actions and simplified them (Katouzian, 2004:300).

Secondly, since in novation, the previous obligation is waived, effect of that is waiver of the former guarantees. Article 293 of Civil Code mentions that "When an obligation is altered, any securities laid down in the original agreement will not be binding under the subsequent agreement, unless the two parties have made express stipulation to that effect". However, in assignment of contract, there is no reason that the former guarantees not be effective, given that in assignment of contract, the contract remains effective. The obtained result is that guarantees and their subordinates will still be maintained and effective and there is no reason that in spite of 
maintenance of the contract, the guarantees be waived.

Thirdly, intentionally assignment of contract, by virtue of the contract being concluded between party to the contract and the third party, would be realized and the original party to the contract would not be considered as the concluder, though his agreement is the condition of assignment of contract. However, in some cases, novation contract between parties to the former legal relationship is concluded, and under some conditions, it is realized with interference of three persons. In novation through altering object of obligation or altering origin of obligation, the obligee and obligor make an agreement and in novation through altering the obligee, written consent of all three parties, obligor, obligee, and the third party (new obligee), is necessary (Shahidi, 2004:151).

Fourthly, novation always occurs through a contract and by intention of parties, while this is the only type of assignment of contract concluding in this form. Sometimes assignment of contract is in a forcible manner due to an irrelevant legal action or a legal event such as death, and sometimes due to a judicial order.

Fifthly, the object of contract related to assignment of contract is a contract as an independent existence, but object of novation is an obligation, so that this obligation can be as a result of a legal action such as a contract, or it can be as a result of a crime or even a tortious guarantee or civil liability. In other words, object of novation is completely different from object of assignment of contract.

\subsection{Sub-Contract}

In Iranian Law, a term with title of "Sub-Contract" doesn't have a legal definition or even legal application. However, in American Law, sub-contract refers to a contract attached to and subject to another contract and second contractor agreement is one of such contracts. For instance, if a person undertakes construction of a building, and assigns whole or a part of work as a result of the contract to another party, sub-contract is established (Black, 1983: 179).

In Iranian Law also sub-contract has numerous legal and practical instances. One of such instances is lease contract. The lessee can rent out the object of lease to a third party. Profit-sharing partnership contract is also another instance of this object and article 554 of Civil Code between the two mentioned states, has caused distinction. According to this article, "The manager may not make a contract of "mudarabah" (profit-sharing partnership) with the same capital, or transfer it to another, without the permission of the proprietor". In Islamic Law also by reviewing books of the jurists, numerous instances of sub-contract can be observed. According to famous viewpoint of the Shiite Jurists, the agent in muzara'eh contract (on agricultural partnership) can hire some people for performing agricultural operation and rent out the land to them and still maintain his partnership in the contract (Yazdi, 1988, Vol.5 :318). Also in mudarabah, the manager for fulfilling some of the procedures which customarily are assigned to some other persons, can hire them or give them powers (Khoei, 1989, Vol.8: 185).

Nevertheless, the most instances of sub-contracts can be found in contractor agreements. In contractor agreements, the main contractor which assigns a part of the operation or obligation of the main contract to sub-contractors, bears direct responsibility of the sub-contractor (second-hand) against him and claims of the sub-contractor shall be borne by the main contractor. However, in some contractor agreements, the employer pays claims of the sub-contractors (even if the employer doesn't have direct relationship with them), and from this aspect, will have a close concept with assignment of contract (Ansari, 1998:287).

In English law, by virtue of FIDIC contract (which is of an international importance) and is a type of template sub-contract agreement, there is a similar status and the employer pays claims of parties to second-hand contracts and of course by mutual agreement (main employer and contractor), there is no impediment for payment of claims of sub-contractors by the main employer (Shoarian, 2009:243).

Though either in assignment of contract or sub-contract a third person enters the legal relationship between parties, or in both of them a legal action of contract type is performed, these two subjects should not be mistake with each other, since:

Firstly, conclusion of a sub-contract only occurs intentionally and a sub-contract never is concluded in a subordinate or forcible manner, while in assignment of contract there are also types of subordinate and forcible and sometimes even a legal event such as death causes assignment of a contract from estate-leaver to heir.

Secondly, assignment of contract in our law requires agreement of the other party to the contract, while conclusion of a sub-contract basically doesn't need obtaining agreement of the other party. Of course, in both subjects being discussed, an stipulation which prohibits assignment of contract or sub-contract would be considered as valid, but if parties remain silent with respect to this issue, the principle of capability of conclusion of sub-contract and incapability of assignment of contract will govern their relationship. Article 541 of Civil 
Code confirms this issue, since according to the said article, the agent in Muzara'eh contract, without consent of the farm lessor, has the right of concluding sub-contract (hiring person), while by virtue of the latter part of the said article, assignment of contract without consent of the farm lessor is not possible.

Thirdly, the most important distinction between these two legal subjects is that in assignment of contract, the assignee is substituted for the assigner and will have a direct contractual relationship with the other party to the contract, so that against fulfilling contractual obligations will be liable against him and also has direct right of claiming contractual rights. While, after concluding a sub-contract, the third person who is party to the sub-contract has no direct relationship with the other main party to the contract and neither is liable against him, nor has direct right of claiming for his rights, and is merely limited to conditions and criteria of the sub-contract, and the principle of relativity of contracts hinders establishment of right for him against other party to the main contract.

In English Law also a subcontractor is not liable against the main party to the contract. In the lawsuit of Stewart against Rearell's Garage, the plaintiff delivered his car which its brakes were damaged to the defendants and according to suggestion of defendants agreed that the contract be performed by subcontractors, but the latter person couldn't fix the car appropriately and as a result of another accident the plaintiff was injured. In this lawsuit it was stipulated that the defendants were entitled for vicarious performance of the contract. However, because of incorrect performance of the subcontractor, they were found liable, and the subcontractor since had no direct relation with the plaintiff was found as having no contractual liability, though a tort could be considered for him because of his fault (Treitel, 1977: 673).

Consequently, the wage amount due to the main contract cannot be claimed by the subcontractor and the main contractor is entitled to claim for wage (Beatson, 1988: 461).

In French Law, assignment of contract is separated from sub-contract. If the obligor substitutes another person for himself, assignment of contract is the object. However, if he maintains his contractual relationship and appoints another person for executing the obligations, the sub-contract would be the object (Shoarian, 2009:245).

Legislator of Egypt, in article 661 of Civil Code has recognized the subcontractor and stipulated that if there is not any opponent term in the contract, the contractor can conclude a sub-contract, and in this case, according to clause 2 of article 661, the contractor will remain liable against the employer. Civil Code of this country has not mentioned assignment of contractor agreement, but as believed by law scholars of this country, assignment of contract wouldn't be prohibited when agreed by the employer. In this case, all rights and obligations due to the contract will be assigned to the second contractor and the first contractor wouldn't be liable anymore (Al-Sanhouri, 1986,Vol.7:208).

According to the aforementioned discussions, it is concluded that assignment of contract cannot be compared with any of the mentioned legal concepts and should be considered as an independent legal subject.

\section{Subjects Similar to Assignment of Contract in International Documents}

In principles of international commercial contracts and also principles of European contracts, besides the subject of assignment of contract, two other contracts are also introduced; one with the title of "assignment of rights" and the other one with the title of "transfer of obligations". In this section, first these subjects are investigated in principles of international commercial contracts and then in principles of European contracts, so that their separation from the subject of assignment of contracts would be simplified.

\subsection{Principles of International Commercial Contracts}

Assignment of rights means that a part of assets of the assigner would be part of the assets of the party to the assignment. The mentioned definition also includes assignment of right as a pledge (Akhlaghi \& Imam, 2006:334), which is mentioned in article 9-1-1 of principles of international commercial contracts.

Transfer of obligations is another subject predicted in principles of international commercial contracts and provides this possibility that the new obligor be replaced with the former. Article 9-2-1 of these principles stipulates that: "Obligation for payment of money or execution of another obligation can be transferred from one person (primary obligor) to another person (new obligor) through one of the following ways:

A. Through mutual agreement between the primary obligor and the new one according to article 9-2-3, or

B. Through a mutual agreement between beneficiary of the obligation and the new obligor, based on which, the new obligor undertakes the obligation of interest". 


\subsection{Principles of European Contracts}

In principles of European contracts also in a similar method, principles of European commercial contracts, subjects of assignment of rights and substitution of new obligor have been considered in addition to subject of assignment of contract:

Article 11-102 of principles of European contracts establishes a principle based on which legal rights are basically able to be assigned. This article stipulates that: " 1) By virtue of articles 11-301 and 11-302 the party to the contract can assign object of the contract. 2) Future right, which will be established based on the existing or future contract can be assigned, provided that at the time it is established, or another time agreed by parties, the said right can be considered as the object of assignment."

This is an international principle that a person can assign his contractual rights, even if it is not still its time. Therefore, either the existing rights or future rights existing in a contract can be assigned. In fact, in many of the legal systems, right of execution besides existing contract is assumed, even if it cannot be claimed for a while (Shoarian, 2010:384).

In principles of European contracts regarding substitution of the new obligor there are two articles that one determines the criteria in brief and in the other one its effects are mentioned. Article 12-101 stipulates that: "1) A third party with agreement of the obligor and obligee can oblige to be replaced with the obligor and its effect is that the original obligor would be free of liability. 2) The obligee can agree in advance to a substitution in the future. In such cases, substitution is only effective when a notice is notified to the obligee by the new obligor according to agreement between the main obligor and obligee."

\subsection{Comparison with Assignment of Contract}

Since each contract from view of each of the parties to it has two sections including rights and obligations, according to the aforementioned discussions, rights and obligations of each of them can be separately assigned. Now, if one party to the contract in a legal action assigns both rights and obligations due to a contract, then in fact an assignment is occurred. In other words, assignment of contract refers to total assignments of rights and obligations. Therefore, in comparing these subjects, assignment of contract is general and the other two are specific.

In assignment of rights, agreement of the party to the contract is not a condition. However in transfer of obligations, agreement and consent of the party to the contract is necessary, whether such agreement is given in advance or will be made in the future. Therefore, when assignment of contract is a resultant of the two mentioned subjects, needs agreement of the other party to the contract, and this agreement with respect to transfer of obligations is considered in assignment of contract. And for this reason in article 9-3-3 of principles of International commercial contracts it is stipulated that: "assignment of a contract requires agreement of the other party" and in article 12-201 of principles of European contracts it is also emphasized that: "1) Party to the contract can agree with a third party that the said person be substituted as party to the contract. In such cases, substitution is only effective as a result of agreement of the other party and in this case the first party would be free of obligation... ."

\section{Conclusion}

Assignment of contract refers to concurrently assignment of rights and obligations of a contract which itself is made in the form of new contract between assignee and assigner and by agreement of the other main party to the contract. This subject in terms of existence of similarities to subjects such as assignment of right, debt, and sub-contract is comparable with domestic law of countries. Also similar subjects to assignment of rights and assignment of obligations in international documents are comparable with the subject of assignment of contract. However, in spite of existence of similarities between each of the said subjects and subject of assignment of contract, there are various differences which separate the subject of assignment of contract from other similar subjects and change it to an independent subject. For instance, in assignment of contract, both rights and obligations are assigned altogether and the third party replaces with one of the main parties to the contract and this issue is only possible by agreement of the other party to the contract. This is while in subjects such as novation, assignment of right, and assignment of debt, sub-contract in domestic laws, and also in subjects of assignment of rights and transfer of obligations in international documents, only a part of effect of the main contract is assigned to the third party and the third party will have no position in the main contract, and sometimes agreement of the other party to the main contract is not necessary. On the whole, it can be stated that assignment of contract compared to other subjects is considered as general and other similar subjects, each cover a specific part of this subject. 


\section{References}

Akhlaghi, B., \& Emam, F. (2006). Principles of International Commercial Contracts. Tehran: Publication of Shahre-Danesh.

Al-Sanhouri, A. (1986). Vol.1 to 7. Beirut.

Ansari, V. (1998). Generalities of Laws of Administrative Contracts. Tehran: Nashre-Hoghughdanan.

Ghasemzadeh, S. M. (2004). Principles of Contracts and Obligations. Tehran: Publication of Dadgostar.

Ghomami, M. (1998). Freedom in choosing party to contract. Journal of high educations of Faculty of laws and Law Sciences of Tehran University. No.1, Tehran.

Jafari Langeroudi, M. (2007). Terminology of Law (Vol. 1-5). Tehran, Publication of Ganje Danesh.

Katouzian, N. (2004). General Principles of Contracts (Vol. 1-5). Tehran: Enteshar Joint Stock Company.

Khoei. S. A. (1987). Book of Mudarabah. Qom: Town of Science.

Korki, A. (1987). Vol.8, Qom: Publication of Al-Beit.

Salajegheh, M. (2000). Contract of assignment of right. Journal of Strategic Management Research, (21/22). Tehran.

Shahidi, M. (2004). Waiver of obligations. Tehran: Majd Publication.

Shoarian, E. (2009). Assignment of Contract. Tabriz. Publication of Foruzesh.

Shoarian, E., \& Torabi, E. (2010). Principles of laws of European contracts and Iranian laws. Tabriz: Publication of Foruzesh.

\section{Note}

Note 1. It seems that the Islamic principle of "Man lahoo alghenam, faalayhe algheram", is comparable with the said principle in English Law.

\section{Copyrights}

Copyright for this article is retained by the author(s), with first publication rights granted to the journal.

This is an open-access article distributed under the terms and conditions of the Creative Commons Attribution license (http://creativecommons.org/licenses/by/3.0/). 